\title{
Growth and freezing tolerance of winterfat seedlings
}

\author{
JUNQIANG HOU AND J.T. ROMO
}

Authors are post-doctoral fellow and professor, Dept. of Crop Science and Plant Ecology, Univ. of Saskatchewan. Saskatoon, Sask. S7N 5A8.

\begin{abstract}
Tolerance to freezing temperatures may be an important factor in the regeneration ecology of winterfat (Ceratoides lanata (Pursh) J.T. Howell). Therefore, growth and freezing tolerance of winterfat seedlings were determined after being grown under different controlled temperatures for 7, 14, 21, or 28 days. Growth of seedlings was greater under day temperatures of 15 and $20^{\circ} \mathrm{C}$ relative to 5 and $10^{\circ} \mathrm{C}$. Freezing tolerance of seedlings was dependent on seedling age and growth conditions. Younger seedlings were more freezing tolerant than older ones grown under the same environmental conditions. Seedlings grown under lower temperatures were more freezing tolerant than those grown under higher temperatures. The lowest observed lethal temperature for $50 \%$ mortality $\left(\mathrm{I}_{\mathrm{T}} \mathrm{T}_{50}\right)$ was $-11.8^{\circ} \mathrm{C}$ for 7 -day old seedlings grown under $10 / 0^{\circ} \mathrm{C}$ alternating temperatures, and the highest $\mathrm{LT}_{50}$ was about $-5^{\circ} \mathrm{C}$ for seedlings 28 days of age when grown under $29 / 1^{\circ} \mathrm{C}$. Based on seedbed temperatures in the field, the results suggest that freezing temperatures may indeed limit the establishment of winterfat seedlings on Northern Mixed Prairie. Seedbeds with litter accumulations or standing dead plant material may ameliorate low temperature extremes and reduce mortality of winterfat seedlings.
\end{abstract}

Key Words: Ceratoides lanata (Pursh) J.T. Howell, Eurotia lanata (Pursh) Moq., cold-hardiness, ecological restoration, Northern Mixed Prairie, seedbed ecology, seedling ecology.

The contribution of shrubs to diversity on the Canadian Prairies has generally been overlooked. Romo et al. (1995) concluded that early range researchers underestimated the importance of winterfat (Ceratoides lanata (Pursh) J.T. Howell), and that its status should be recvaluated. Winterfat is well known for its supcrior forage quality (Clarke and Tisdale 1945, Smoliak and Bezeau 1967). There is considerable interest in using the shrub for restoration and improvement of rangelands on the Canadian Prairies. Researchers have recognized that seedling mortality is a major obstacle to the establishment of this shrub, and it is suspected that freezing temperatures may play an important role in limiting its establishment (Hodgkinson 1975, Booth 1987). Despite observations of germination under snow (Hilton 1941, Woodmansee and Potter 1971), freezing tolerance of winterfat

\footnotetext{
This research was jointly funded by Saskatchewan Agriculture Development Fund Project, the Canada-Saskatchewan Agriculture Green Plan Agreement and Ducks Unlimited Canada. Thanks are extended to Mike Boyachek for advice on freezing tests and use of equipment, and to Drs. Y. Bai, D.T. Booth, and L. Gusta for manuscript reviews. JTR is corresponding author.

Manuscript accepted 26 Apr. 1996.
}

during early development is poorly described. Fry (1969) observed that acclimated younger seedlings survived freezing temperatures better than older, unacclimated ones. Booth (1987) demonstrated an equilibrium freezing process in germinants where the radicle, but not the cotyledons, had emerged from the bracts. Bai et al. (1996) recently found that germination was not affected after exposure of hydrated winterfat seeds to temperatures as low as $-30^{\circ} \mathrm{C}$.

The purpose of this study was to: 1) comparc the effects of temperature on seedling growth of winterfat, and 2) characterize freezing tolerance in winterfat seedlings grown under different environmental conditions for various periods of time. This information will be useful for estimating the influence of freezing temperatures on establishment of winterfat in the field.

\section{Materials and Methods}

\section{Study Area}

Winterfat diaspores were collected in late September 1994, at the Matador Research Station $\left(50^{\circ} 42^{\prime} \mathrm{N}, 107^{\circ} 43^{\prime} \mathrm{W}\right.$. elev. $\left.685 \mathrm{~m}\right)$ of the University of Saskatchewan, about $70 \mathrm{~km}$ north of Swift Current, Saskatchewan. The diaspores were stored in paper bags at room temperature until used. The diaspore bracts were removed by hand and seeds were used for growing seedlings throughout the experiments.

Vegetation at the Matador Research Station is classified as the Agropyron-Koeleria Faciation of Mixed Prairie (Coupland 1950), but winterfat is a common and distinctive shrub (Romo et al. 1995). Mean daily temperatures at Swift Current average $3.7^{\circ} \mathrm{C}$ in April and $10.3^{\circ} \mathrm{C}$ in May; maximum temperatures can exceed 27 and $32^{\circ} \mathrm{C}$ in April and May, respectively (Environment Canada 1982). Minimum temperatures can be as low as $-27^{\circ}$ and $-12^{\circ} \mathrm{C}$ for the same periods. Temperatures of -36 and $-3^{\circ} \mathrm{C}$ have been recorded in March and June, respectively. Annual prccipitation averages $327 \mathrm{~mm}$ with approximately two-thirds being received as summer rain. Soils in the area are Rego Brown and Calcareous Brown Series in the Sceptre Association of the Chernozemic Brown Subgroup (Aridic Borolls)(Coupland et al. 1974).

Data loggers with temperature sensors were placed in the field at the Matador Research Station in 1991, 1992, 1994, and 1995 to continuously monitor air and seedbed temperatures during April and May. These months were chosen because winterfat seedlings emerge in early April when there is a high risk of freezing temperatures occurring. Seedlings emerge either from bare soil or from beneath litter, therefore, the temperature sensors were placed beside naturally dispcrsed diaspores on the soil surface and on the soil surface beneath litter. Air temperatures were recorded $1 \mathrm{~m}$ above ground level. 


\section{Temperature Effects on Seedling Growth}

Seeds were incubated at $18^{\circ} \mathrm{C}$ in darkness in plastic boxes that were lined with 2 layers of wet, No. 1 Whatman filter paper. After 5 days seedlings that were approximately $3-\mathrm{cm}$ long were selected and 3 each were transplanted into $125 \times 100 \mathrm{~mm}$ pots filled with wet "Redi-earth" media. The moisture content of the soil was maintained at a ratio of $1.5: 1$ water to soil by weight with daily watering. The pots were placed in controlled environment chambers at all 8 combinations of 0 or $5^{\circ} \mathrm{C}$ night temperature and $5,10,15$, or $20^{\circ} \mathrm{C}$ day temperatures. Light $\left(220 \mu \mathrm{mol} \mathrm{m} \mathrm{m}^{-2}\right.$ $\mathrm{s}^{-1}$ ) was supplied for 14 hours during the warm cycle. Relative humidity was set at $50 / 70 \%$ for day/night cycles. Fourteen days after planting, the 2 smallest seedlings in each pot were removed. After 28 days of growth, seedling height and leaf area (Li-3000A, Li-Cor, Inc. Lincoln, Neb.) were measured. Roots were carefully washed from the "Redi-earth" by hand, and shoots and roots were weighed after drying at $70^{\circ} \mathrm{C}$ for 5 days. The experiment was a completely randomized block design with 28 replicates per treatment and it was repeated.

\section{Freezing Tests}

Seeds were soaked for 4 hours in a $600 \mathrm{mM}$ ethanol solution at room temperature, thoroughly washed in distilled water and then soaked in distilled water overnight on a horizontal shaker at a speed of 50 strokes minute ${ }^{-1}$. The ethanol treatment provided synchronous germination needed to ensure seedlings were of uniform age (Hou and Romo, unpub. data). Seeds with radicles protruding through the testa, but $<1 \mathrm{~mm}$ were selected and 3 were transferred to each cell of $2 \times 2.2 \times 10 \mathrm{~cm}$ root trainers (Spencer-Lemaire Industries Ltd, Edmonton, Alberta) filled with loose, moist "Redi-earth" media. The seeds were covered with a thin layer of "Redi-earth", and the surface was sprayed with water daily until seedlings emerged. Drilling a small hole several $\mathrm{cm}$ into the soil and directing the radicle into the hole helped root development and seedling establishment. The seedlings were grown in growth chambers at $10 / 0$ or $15 / 5^{\circ} \mathrm{C}$ for $7,14,21$, or 28 days. Light and humidity were set as previously described. Plants were watered every 3 days by soaking the root trainers for $30 \mathrm{sec}-$ onds in trays filled with water to a $5-\mathrm{cm}$ depth. Before freezing tests, seedlings were lightly pulled with a pair of forceps, and poorly rooted seedlings were removed. The root trainers were then placed in an environmental chamber at $4^{\circ} \mathrm{C}$ for 4 hours to prevent temperature shock. These seedlings were then transferred to a programmable freezing system described by Gusta et al. (1978), and held at $-3^{\circ} \mathrm{C}$ for 18 hours to allow the freezing process to reach equilibrium. The temperature was then decreased at $2^{\circ} \mathrm{C}$ hour ${ }^{-1}$ to $-21^{\circ} \mathrm{C}$ over 9 hours.

Seedlings were removed at $-3,-5,-7,-9,-11,-13,-15,-17$, -19 , and $-21^{\circ} \mathrm{C}$ and transferred to $4^{\circ} \mathrm{C}$ for 24 hours before being returned to the controlled environment chambers. The control seedlings were kept at $4^{\circ} \mathrm{C}$ in darkness for the period of freezing tests. Seedling height and weight were determined from 10 randomly selected seedlings for each age group at the time of freezing. Seedling mortality was determined after 14 days of growth at $15 / 5^{\circ} \mathrm{C}$. There were 2 replicates, each of which had 12 cells with 17 to 25 seedlings, for each test temperature. Replicates were randomly assigned to test temperatures, and experiments were repeated.

For the experiment in which seedlings were grown under environmental conditions that simulated spring temperatures in southern Saskatchewan (Environment Canada 1982), seedlings were grown at $17 /-2^{\circ} \mathrm{C}$ day/night for the first 7 days. Temperatures were then increased to $21 /-1,25 / 0$, and $29 / 1^{\circ} \mathrm{C}$ in the second, third, and fourth weeks, respectively. Temperatures were ramped so seedlings experienced 2 hours of the minimum temperature before dawn, and 6 to 8 hours of the maximum during day. The light cycle was 14 hours for the first 7 days and then was increased by 0.5 hours for each of the following 7-day periods. Seven, 14, 21, and 28-day old seedlings were subjected to freezing tests as described above.

\section{Data Analysis}

Growth parameters were analyzed with analysis of variance, and LSD $(P \leq 0.05)$ was used to separate means. Probit analysis (Finney 1971, SAS Institute Inc. 1990) was applied to the results of the freezing tests. Model fit was determined by Pearson Chisquare and L.R. Chi-square goodness-of-fit tests ( $P \geq 0.10)$ (SAS Institute Inc. 1990). The lethal temperature for $50 \%$ and $95 \%$ mortality $\left(\mathrm{LT}_{50}\right.$ and $\left.\mathrm{LT}_{95}\right)$ along with their $95 \%$ fiducial limits were determined from the model estimates. Values without overlapping fiducial limits were considered significantly different.

\section{Results}

\section{Temperatures in the Field}

Monitoring of air temperatures in the field during April and May revealed that minimum daily temperatures could be potentially damaging to plants (Fig. 1). Temperatures fell below $-10^{\circ} \mathrm{C}$ in all periods of sampling except May 1995 when the minimum temperature was $-9^{\circ} \mathrm{C}$. Minimum temperatures on the soil surface were nearly the same as air temperatures; however, temperatures under litter were about $2^{\circ} \mathrm{C}$ warmer than those of the air and soil (data not shown).

\section{Seedling Growth and Freezing Tolerance}

Growth was accelerated when day temperatures were above $10^{\circ} \mathrm{C}$ (Fig. 2). The growth of seedlings was generally enhanced
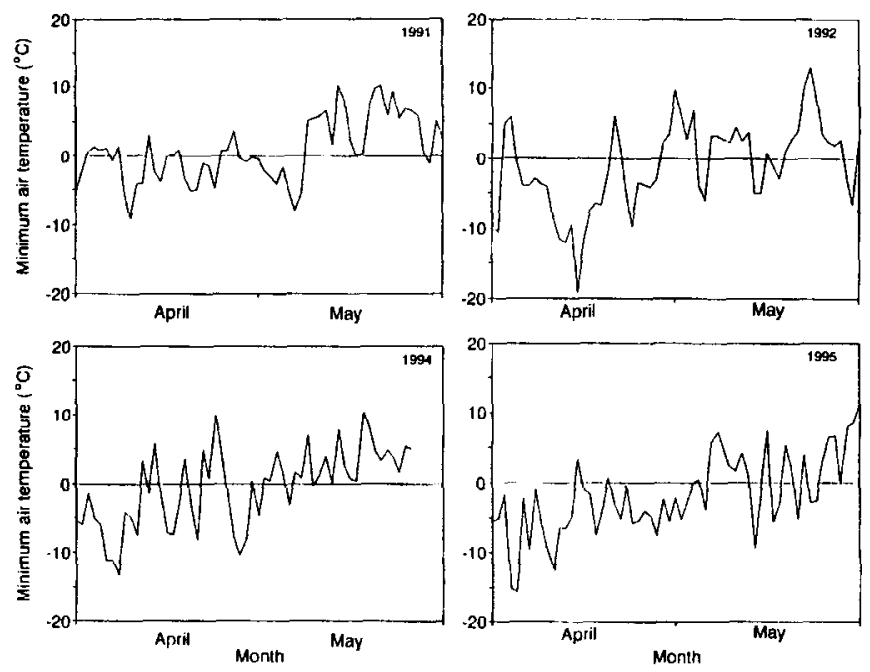

Fig. 1. Minimum daily air temperatures recorded in April and May at the Matador Research Station in April and May 1991, 1992, 1994 , and 1995. 

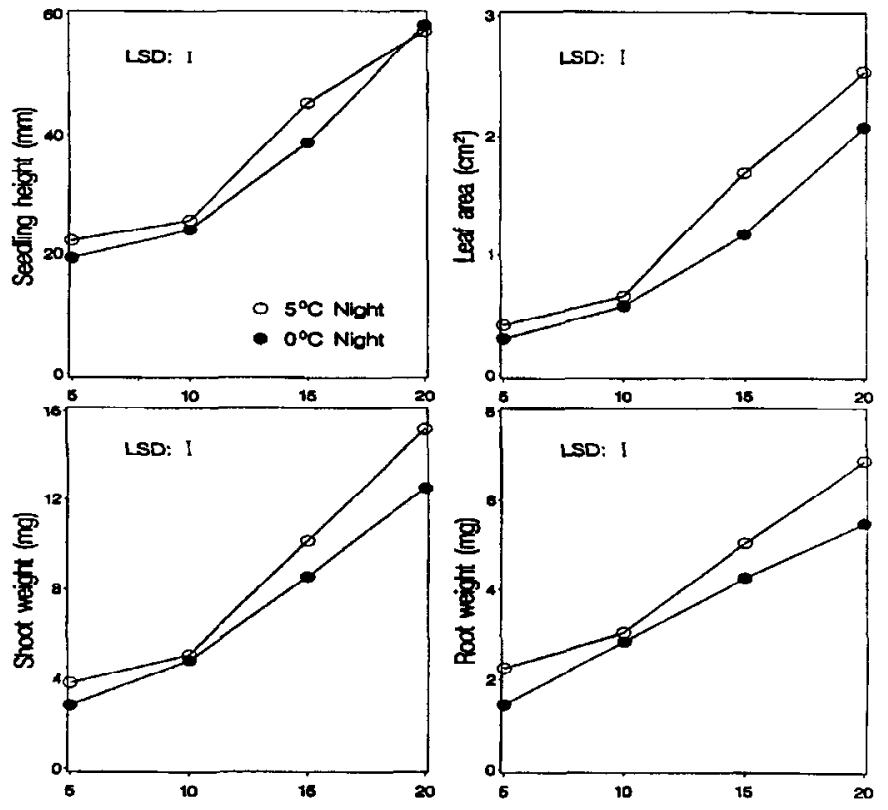

Day temperature $\left({ }^{\circ} \mathrm{C}\right)$

Fig. 2. Growth of winterfat seedlings after 28 days under 8 different temperature regimes. Each point is the mean of 56 replicates.

by increasing night temperatures when day temperatures were 15 or $20^{\circ} \mathrm{C}$, but the effects of night temperatures were not significant in most cases when day temperatures were 5 or $10^{\circ} \mathrm{C}$.

Fewer seedlings died that had been grown under $10 / 0^{\circ} \mathrm{C}$ as compared to those grown at $15 / 5^{\circ} \mathrm{C}$ after subsequent exposure to freezing temperatures (Fig. 3). The $\mathrm{LT}_{50}$ and $\mathrm{LT}_{95}$ for seedlings

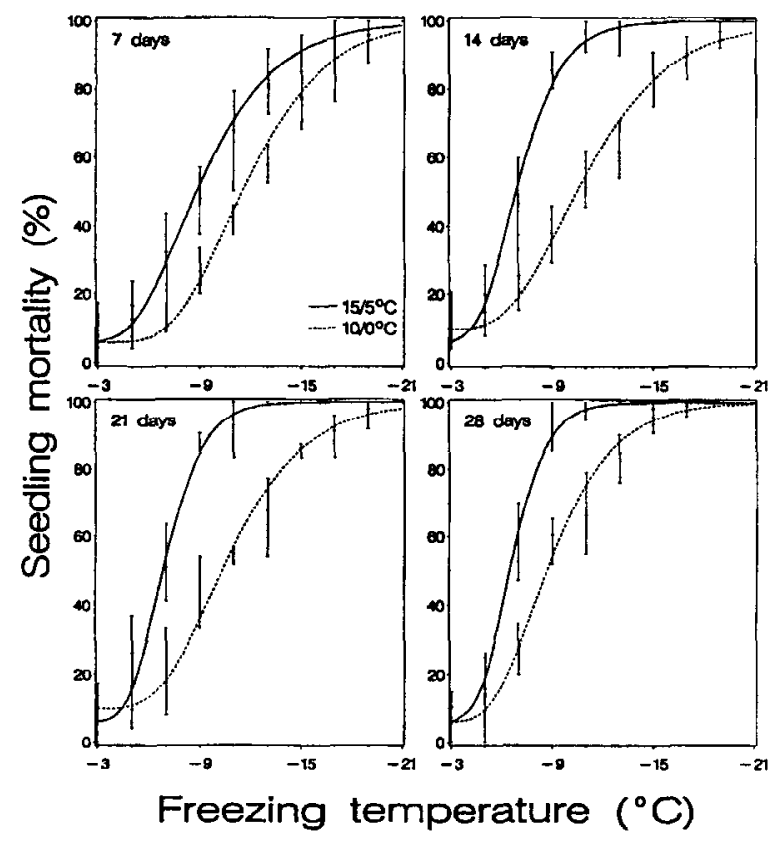

Fig. 3. Percent mortality of winterfat seedlings that were 7, 14, 21 or 28 days of age after exposure to freezing temperatures when grown under $10 / 0$ or $15 / 5^{\circ} \mathrm{C}$ day/night. Each bar is the maximum, minimum and mean mortality observed for 4 replicates.

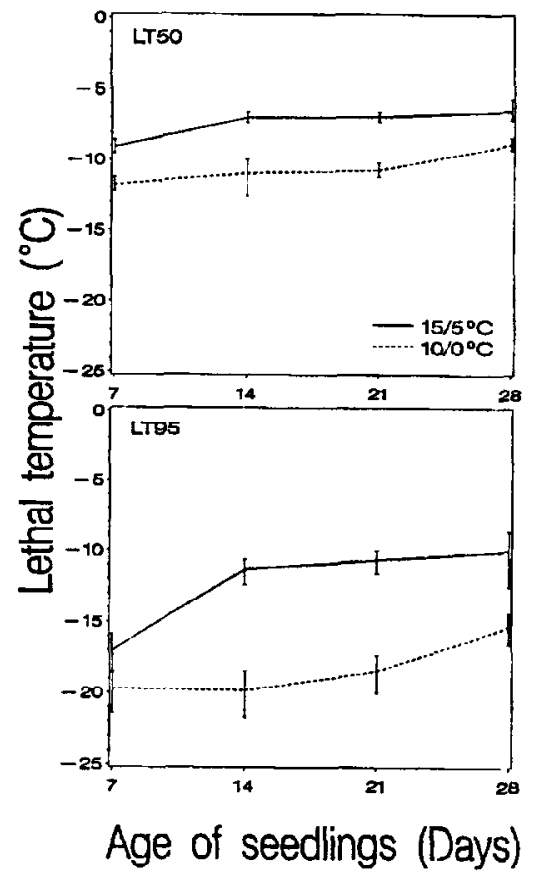

Fig. 4. Lethal temperatures $\left({ }^{\circ} \mathrm{C}\right), \mathbf{L T}_{\mathbf{5 0}}\left(50 \%\right.$ mortality) and $\mathrm{LT}_{95}$ (95\% mortality) for winterfat seedlings that were $7,14,21$, or 28 days of age and grown under $10 / 0^{\circ} \mathrm{C}$ or $15 / 5^{\circ} \mathrm{C}$ day/night. Bars represent the $95 \%$ fiducial limits.

initially grown at $10 / 0^{\circ} \mathrm{C}$ were significantly lower than those grown at $15 / 5^{\circ} \mathrm{C}$ (Fig. 4). When grown under same conditions, the $\mathrm{LT}_{50}$ and $\mathrm{LT}_{95}$ tended to increase with seedling age. The situation was similar for 14,21 , and 28-day old seedlings grown under $15 / 5^{\circ} \mathrm{C}$ compared to those that were 7 -days of age. The increased $\mathrm{LT}_{50}$ and $\mathrm{LT}_{95}$ apparently coincided with the increased growth of the seedlings (Table 1).

When seedlings were grown under temperatures simulating those of spring, increasing temperatures promoted seedling growth (Table 2), and freezing tolerance of seedlings decreased (Fig. 5). For example, the $\mathrm{LT}_{50}$ was $-6^{\circ} \mathrm{C}$ for the 14-day old seedlings that received $21 /-1^{\circ} \mathrm{C}$ treatment during the last 7 days (Fig. 6), which contrasted with $-9^{\circ} \mathrm{C}$ for the 7-day old seedlings exposed to $17 /-2^{\circ} \mathrm{C}$. A freeze test-temperature of $-9^{\circ} \mathrm{C}$ eliminated the seedlings which were growing rapidly at these warm day temperatures (Fig. 6).

Table 1. Height and dry weights of shoots of winterfat seedlings before being subjected to freczing temperatures. Seedlings were grown at $10 / 0$ or $15 / 5^{\circ} \mathrm{C}$ in $14 / 10$ hours day/night regime. Fach value is the mean $\pm S E$ of 20 seedlings.

\begin{tabular}{|c|c|c|c|c|}
\hline \multirow{2}{*}{$\begin{array}{l}\text { Temperature } \\
\text { regime } \\
\text { (day/night) }\end{array}$} & \multicolumn{4}{|c|}{ ( $\ldots \ldots \ldots$ - Seedling age (days) $\ldots \ldots$} \\
\hline & 7 & 14 & 21 & 28 \\
\hline \multicolumn{5}{|l|}{$\left(10 / 0^{\circ} \mathrm{C}\right)$} \\
\hline Height (mm) & $6.8 \pm 0.3$ & $15.0 \pm 0.6$ & $18.3 \pm 0.9$ & $23.2 \pm 1.0$ \\
\hline Weight (mg) & $1.1 \pm 0.1$ & $1.6 \pm 0.1$ & $1.9 \pm 0.1$ & $3.4 \pm 0.2$ \\
\hline \multicolumn{5}{|l|}{$\left(15 / 5^{\circ} \mathrm{C}\right)$} \\
\hline Height (mm) & $11.3 \pm 0.8$ & $24.3 \pm 0.7$ & $31.4 \pm 0.5$ & $43.6 \pm 1.1$ \\
\hline Weight (mg) & $1.4 \pm 0.1$ & $2.5 \pm 0.1$ & $4.2 \pm 0.1$ & $7.4 \pm 0.5$ \\
\hline
\end{tabular}




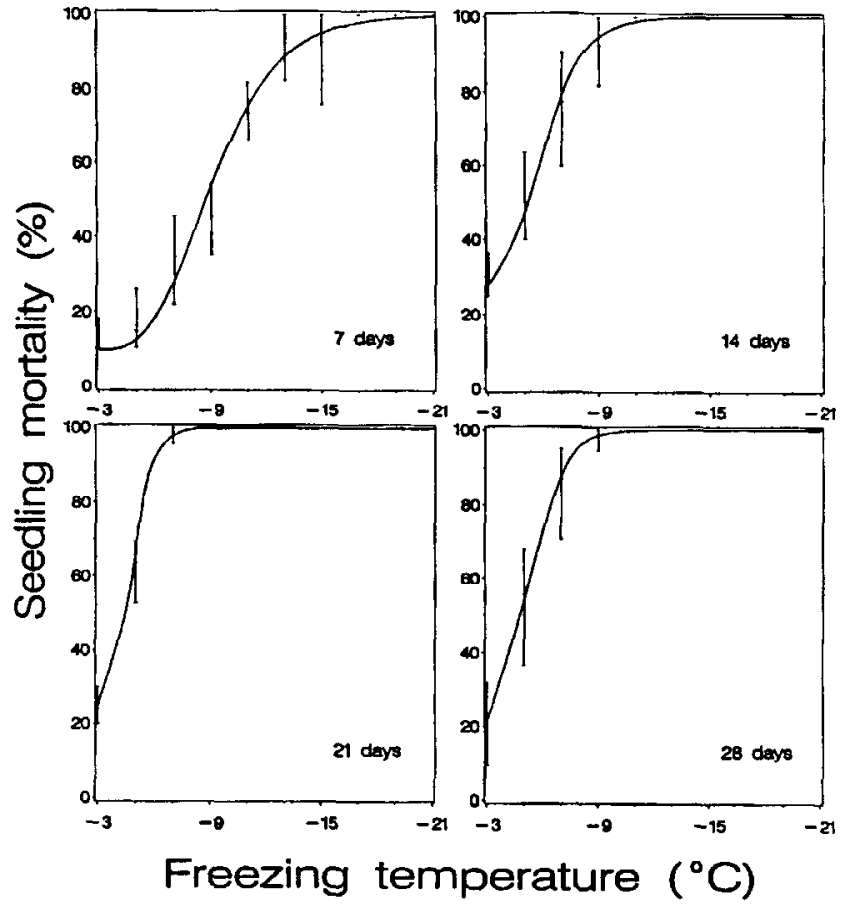

Fig. 5. Percent mortality in winterfat seedlings that were $7,14,21$, or 28 days of age and grown under environmental conditions that simulated spring weather in the Canadian Prairies and exposed to freezing temperatures. See text for the temperature and light regime descriptions. Each bar is the maximum, minimum and mean mortality observed in 4 replicates.

Since the mortality of the controls within age groups was not significantly different between freezing tests, the data were pooled according to age groups. The mean mortality $( \pm \mathrm{SE})$ was $6.6 \pm 1.1,7.5 \pm 1.2,7.1 \pm 1.2$, and $2.5 \pm 1.0 \%$ for $7,14,21$, and 28 -day old seedlings, respectively.

Table 2. Height and dry weights of shoots of winterfat seedlings before being subjected to freezing temperatures. Seedlings were grown under environmental conditions that simulated spring weather in the Canadian Prairies. See text for the temperature and light regime descriptions. Each value is the mean \pm SE of 20 seedlings.

\begin{tabular}{|c|c|c|c|c|}
\hline & \multicolumn{4}{|c|}{$\ldots \ldots-$ Seedling age (days) $\ldots \ldots$} \\
\hline & 7 & 14 & 21 & 28 \\
\hline Height (mm) & $8.6 \pm 0.5$ & $22.5 \pm 0.9$ & $40.0 \pm 1.7$ & $60.5 \pm 2.0$ \\
\hline Weight (mg) & $1.2 \pm 0.1$ & $2.7 \pm 0.1$ & $5.7 \pm 0.3$ & $14.4 \pm 0.8$ \\
\hline
\end{tabular}

\section{Discussion and Conclusions}

Many temperate plants are capable of developing freezing tolerance following a period of low temperature exposure (generally temperatures colder than $10^{\circ} \mathrm{C}$ ) (Levitt 1980 , Guy 1990). This acclimation process is under genetic control and is induced primarily by low temperatures and in some cases by a short photoperiod. Returning the plants to nonacclimating conditions generally results in a loss of freezing tolerance. The results of the present freezing tests indicate that winterfat is not an exception to

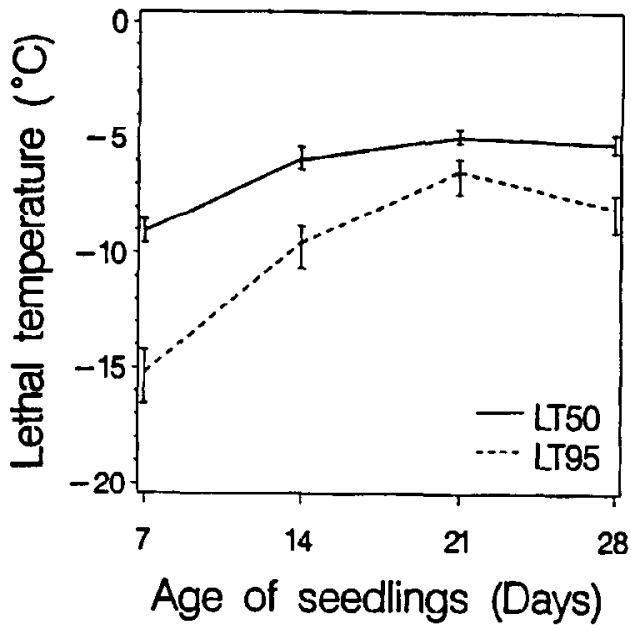

Fig. 6. Lethal temperatures $\left({ }^{\circ} \mathrm{C}\right), \mathrm{LT}_{50}\left(50 \%\right.$ mortality) and $\mathrm{LT}_{\mathbf{9 5}}$ (95\% mortality), for winterfat seedlings that were $7,14,21$, or 28 days of age and grown under environmental conditions that simulated spring weather in the Canadian Prairies. See text for the temperature and light regime descriptions. Bars represent the 95\% fiducial limits.

this general concept. Increased freezing tolerance can be acquired by seedlings grown under low temperatures. Freezing tolerance, on the other hand, can be reduced by environmental conditions which promote growth, i.e. warm temperatures. A reduction in freezing tolerance can occur within 1 week, the shortest period examined in this study.

The present study demonstrated that smaller plants, either younger seedlings or grown under lower temperatures, were more tolerant to lower freezing temperatures than their larger counterparts. This response is in good agreement with Fry's (1969) observation that younger winterfat seedlings survived lower temperatures than older ones. The relationship between plant size and freezing tolerance varies with species although cold acclimation has been associated with slower plant growth (Levitt 1980, Guy 1990). Ashworth et al. (1985) reported that ice nucleation in smaller plant samples occurred at lower temperatures than in larger ones possibly because of a reduced probability of a nucleation event. Olien (1964) described freezing patterns in different tissue types in the crown of barley (Hordeum vulgare L.). Equilibrium freezing processes typically occur in regions where the tissues are uniform and the protoplasts are young and active. The formation of ice between cells causes dehydration as liquid water moves out of the cells to extracellular ice crystals. Mechanical damage to tissues may be minimized as the cells contract in the process. Non-equilibrium freezing processes typically occur in regions containing differentiated tissues with transitional boundaries. Large ice crystals may form in places such as the vascular elements due to the high moisture content and in turn mechanically injure the tissues. Booth (1989) demonstrated an equilibrium freezing pattern in winterfat germinants and elicited the relationship between the observed freezing tolerance and tissue differentiation. In a recent study on the tolerance of desiccation in winterfat seedlings, air-dried germinants with a radicle protruding several $\mathrm{mm}$ were revived upon rehydration (Hou and Romo unpub. data). Therefore, the above factors such as reduced probability of ice nucleation, less mechanical injury, and high 
dehydration tolerance might contribute to increased freezing tolerance in small winterfat seedlings.

The $\mathrm{LT}_{50}$ determined in the present study ranged from -11.8 to about $-5^{\circ} \mathrm{C}$, depending on the age and temperature under which seedlings were grown. Winterfat consistently germinates in late March or early April in southern Saskatchewan (Romo unpub. data). This observation combined with the fact that temperatures to $-19^{\circ} \mathrm{C}$ were recorded in April and May suggests that many winterfat seedlings may be killed by freezing temperatures in early spring. Temperatures recorded in the field under litter were about $2^{\circ} \mathrm{C}$ warmer than on bare soil or in the air in early spring. Therefore maintaining seedbed characteristics such as litter accumulations or standing dead plant material to provide protection and ameliorate these temperature extremes may be important for successful establishment of winterfat seedlings. It is also possible that a warm spring may be needed for establishment of winterfat.

The above argument also applies to the culture of this shrub. A period of low temperature $\left(5^{\circ} \mathrm{C}\right)$ imbibition of seed enhanced post-germination growth of winterfat; therefore, Booth (1992) recommended late fall or winter seeding to take advantage of the cool and high moisture conditions in early spring. In Saskatchewan seedling emergence of winterfat is superior in fall versus spring seeding (Zabek and Romo unpub. data). Observations of others (Hilton 1941, Fry 1969, Woodmansee et al.1971) and the present study indicate that there is a good chance of winterfat seedlings surviving freezing temperatures in early spring if they are small. Seeding in late fall or winter, therefore, should normally be a good practice for the culture of the shrub so that the maximum growth can be achieved in the following growing season. The real danger to survival is from freezing events that occur after short periods of warm weather that encourage fast growth of seedlings. In regions where late spring frost is a frequent event, alternative practices, such as spring seeding and plant transplantation after the period with a high risk of frost has passed, may have to be considered. A negative aspect of spring seeding is that the period for growth of seedlings will be shortened and they may not develop adequately to survive the following winter.

This study established the freezing tolerance of winterfat seedlings in the period immediately following emergence. Assuming that winterfat seedlings survive their first growing season, surviving in freezing temperatures during the first autumn through spring may be the next critical phase in their establishment.

\section{Literature Cited}

Ashworth, E.N., G.A. Davis, and J.A. Anderson. 1985. Factors affecting ice nucleation in plant tissues. Plant Physiol. 79:1033-1037.

Bai Y., Booth D.T., and J.T. Romo. 1996. Freezing tolerance in winterfat (Eurotia lanata (Pursh) Moq.) seeds. Part II: Survival of hydrated seeds is not related to low temperature exotherm (in review).

Booth, D.T. 1987. Contributions to the reproductive autecology of winterfat (Eurotia lanata (Pursh) Moq.) with notes on direct seeding methods. Ph.D. Dissertation, Univ. of Wyoming, Laramie, Wyo.

Booth, D.T. 1989. A model of freeze tolerance in winterfat germinants. p. 83-89. In: A. Wallace, M.R. Haferkamp and E.D. McArthur (compilers). Shrub ecophysiology and biotechnology-Fifth wildland shrub symposium. Gen. Tech Rep. INT-256. USDA, Forest Service, Intermountain Res. Sta., Ogden, Ut.
Booth, D.T. 1992. Seedbed ecology of winterfat: Imbibition temperature affects post-germination growth. J. Range Manage. 45:159-164.

Clarke, S.E. and A.W. Tisdale. 1945. The chemical composition of native forage plants of southern Alberta and Saskatchewan in relation to grazing practices. Dominion of Canada, Dep. of Agr. Tech. Bull. 54. Publ. No. 769.

Coupland, R.T. 1950. Ecology of mixed prairie in Canada. Ecol. Monogr. 20:271-315.

Coupland, R.T., J.R. Willard, and E.A. Ripley. 1974. Summary of activities, 1967-1974. Matador Project Tech. Rep. No. 69. Univ. of Saskatchewan. Saskatoon.

Environment Canada, Atmospheric Environmental Service. 1982. Canadian climate normals (1951-1980), Temperature and precipitation (prairie provinces). Ottawa, Canada.

Finney, D.J. 1971. Probit analysis. Third Edition. Cambridge Univ. Press. London.

Fry, W.C. 1969. The response of Atriplex canescens and Eurotia lanata to subfreezing temperatures. MS Thesis, Univ. of New Mexico, Albuquerque, N.M.

Gusta, L.V., M. Boyachek, and D.B. Fowler. 1978. A system for freezing biological materials. Hort. Sci. 13:171-172.

Guy, C.L. 1990. Cold acclimation and freezing stress tolerance: Role of protein metabolism. Annu. Rev. Plant Physiol. 41:187-223.

Hilton, J.W. 1941. Effects of certain micro-ecological factors on the germinability and early development of Eurotia lanata. Northw. Sci. 15:86-92.

Hodgkinson, H.S. 1975. Evaluation of winterfat (Eurotia lanata) in Washington. J. Range Manage. 28:138-141.

Levitt, J. 1980. Responses of plants to environmental stresses, No.I. Chilling, freezing, and high temperature stresses. 2nd ed. Academic Press. N.Y.

Olien, C.R. 1964. Freezing processes in the crown of 'Hudson' barley, Hordeum vulgare (L., emend. Lam.) Hudson. Crop Sci. 4:91-95.

Romo, J.T., R.E. Redmann, B.L. Kowalenko, and A.R. Nicholson. 1995. Growth of winterfat following defoliation in Northern Mixed Prairie of Saskatchewan. J. Range Manage. 48:240-245.

SAS Institute Inc. 1990. SAS/STAT user's guide. Version 6, 4th ed. SAS Inst. Inc., Cary, N.C.

Smoliak, S. and L.M. Bezeau. 1967. Chemical composition and in vitro digestibility of range forage plants of the Stipa-Bouteloua prairie. Can. J. Plant Sci. 47:161-167.

Woodmansee, R.G. and L.D. Potter. 1971. Natural reproduction of winterfat (Eurotia lanata). J. Range Manage. 24:24-30. 